\title{
Historical-Anthropological Ethno-Genesis of Albanian Society Development, Especially the Gjakovar with Surrounding One
}

\author{
Bekim Avdiaj \\ PhD Candidate at the European University of Tirana, Social Sciences \\ Lumnije Avdiaj \\ MSc on Economics, College "Biznesi"
}

\begin{abstract}
Albanian society inherits an ethno-genesis since ancient ages. Part of this, is also the Gjakovar society with surrounding. Through development phases, as many other societies, this one faced with challenges from the most different. Among the main ones was the war for surviving from numerous invaders, and that until the last decade of the $20^{\text {th }}$ century. Of course that all of them who had claims toward these lands, they tried through different ways, to make the history of this society as their own, alluding that this population wasn't existent in this land. However, the Albanian society managed to survive all historical periods and that by keeping its genesis clear. It had been achieved through 'inherits' guides of traditions and culture over generations, and that, leaving deep footprints not only for itself, but even for the stories of neighbor societies. So, through this study, we will try to tell how the society of Gjakova region has kept its ethno-genesis, proving that it was a unique part of Albanian society and that was one of the very first in Europe. We will prove it through showing historical-anthropological fact since the antiquity to the newest artifacts. To clarify that this population is really autochthonous in this land, it is told also by saving and taking-after the cultural heritage. As an argument it is also the keeping of surnames based on cultivated artisans through ages, which are still being held by a part of this population.
\end{abstract}

Keywords: culture, heritage, artifacts, habits and traditions

\section{Introduction}

Nowadays science has managed to prove that the Albanian nation, being one of the oldest nation in Europe, during their journey and development throughout history has experienced a journey with many obstacles and stops.

Its geographical and geo-strategic position had placed them at the crossroad of all crossroads that outlined social developments of all time, which became a cause and a target of political interests of countries and numerous invaders, starting from the Roman Empire, the Byzantine, Slavic invasions, Ottoman empire and up to the great powers of the past century.

It was precisely these that in different forms tried to eradicate the Albanian people, ranging from assimilation and up to its biological liquidation. This is also proven by that that when in the territory of Kosovo today, in medieval times were changed many rulers, such as the Romans, Byzantines, Bulgarians, Macedonians, Serbs and Turks, to continue later, until recent years of $X X$ century.

Whenever it comes to researching the distant past, science constantly continues to uncover new facts and documents, as every day new artefacts are discovered, which in some cases deny the ones so far.

This is also enabled by the modern tools of the latest technology, which enable explanations by more advanced methods.

History shows various forms of social organization, depending on the invaders who changed, so from the Romans to the Slavs of the twentieth century. Despite this, all settlements in Kosovo managed to build and preserve its history and of whole Kosovo. 
Some previously created some later, with changes in designations and history, first Roman, then Byzantine, Slavic, Bulgarian, Ottoman again Slavic, with persecuted and mutilated population, but never submissive, ultimately remained pure Albanian settlements since their genesis.

One of the earliest settlements and with a pure and proud history, proven through various times in history, since ancient times is also the settlement called Gjakova and its surroundings.

\section{Historical-Anthropological ethno-genesis of the development of Albanian society}

Referring to the numerous researches and studies by different researchers we have now proven the accurate genesis of the Albanian people since ancient history and its role and that from ancient times until today. Researches show that since the creation of the Illyrian family and their tribal union up to the building of Illyrian-Dardan state, not leaving aside also the luck that accompanied it throughout history.

Illyrians were great people, made up of many tribes, which, even if they sometimes had separate tribal organization, or the state itself, they were cooperative and solidary with other tribes; they had a common culture, one tradition and one territory and thus belonged to the Illyrian ethnic trunk. (Krasniqi, 2002) That the Albanian people is a descendant of the ancient Illyrians and Illyria, is confirmed today by science through many researchers from different countries, who provide convincing proves.

So even today we prove that predecessors of the Albanians were living in a large space, almost the entire Balkan Peninsula, and were in a large number as indigenous and homogeneous ethnicity.

Among many studies and researches is also that of 1877 in Germany, where for the first time we have an anthropological study on Albanians, which identifies Albanians with Illyrians. It was a pathologist and anthropologist Rudolf Virhov (18211902), known as the "founder of cellular pathology," a prominent figure of the science of the last century, who came up with this study. (Këpuska, 2004) From here began the anthropology of Albanians. So, obviously, the Albanians are descendants of old lllyrians old.

They are indigenous in the Balkan countries where they were spread before the pre-national period and their seniority lies at least in the Mediterranean- Pelasgian historical period respectfully Epical-Homeric period. We mentioned these historiographical data because the culture, Albanian traditions and rituals, draw the roots in the twilight of time. Spiritual and material culture of the ancestors of the Albanian people serves as the basis, respectively adstrat, but also superstrat of the spiritual and material culture of surrounding nations located in the Illyrian territories in the ancient and medieval period. (Pirraku, 1989)

Science has proven that the Albanians are direct descendants of the ancient Illyrians. So, Albanians and Greeks are the oldest people in the Balkans, permanent residents of the geographic area for thousands of years before Slavic tribes arrived in these parts from their lands beyond the Carpathian. (Krasniqi, 2002)

Regarding Illyrian - Dardani, their lands and heritage, especially the social customs, traditions and ethnic autochthony, compacts as; natural, historical, political, ethnographic, ranging from ancient authors and onwards, chronologically are treated proving sources over the actual existence and progress through periods from Homer and up to the VII century.

During these periods' nations bordering Illyrian - Dardan, some were assimilated and some were vanished entirely, until they stood proudly preserving pure origins and traditions of ancient Illyrian-Albanians.

Illyrian traditions, described by many scholars, among them also Varrioni, are passed from generation to generation to their descendants - Albanian men and women today. (Këpuska, 2004)

Survival of the Albanian people since antiquity is presented in this way "Described as if it was a survived and all-timely Arcadia, she was believed to be inhabited by primitive people, free and courageous, carriers of millennial invariable traditions codified by Law of the Mountains influenced by a hostile geographical environment and archaic living conditions, a builder of people's characters, their customs and ancient trends ". (Rago, 2011) 
Despite many centuries' Storms, which had even more damaging consequences, Illyrian-Dardans continued to maintain their ethno-genesis? One may justifiably conclude that ethno-genesis of our people starts from caves to continue forward with its development until today. So antiquity of Illyrian-Dardans is known not only for the Balkans and Europe, but also across the globe.

They already stretched as homogeneous and indigenous ethnicity in most of the Balkan Peninsula. This is why they are also regarded as one of the oldest people of this peninsula. This is even said by the American researcher William W. Howard who wrote that Albania "is the most ancient nation of Europe. . . They were there long before Helens established the ancient Greece". (Osmani, 2010)

Historical developments dictated that this people experienced many movements, especially in its trunk, by different invaders taking over their lands. There were precisely many difficulties during centuries imposed this people to find different ways to protect their genesis and land.

Today science has managed to demonstrate and prove that the Albanian people during the journey and development through history, being among the oldest peoples of Europe had experienced a journey with many obstacles and stops. Its geographical and geo-strategic position had been at the crossroads of all crossroads outlining social developments of all time, which became a cause and targeted political interests of countries and numerous invaders, starting from the Roman Empire, the Byzantine, invasions Slavic, Ottoman empire to the great powers of the past century.

New settlements of Slavic travellers in Balkan Peninsula in VI-VII century and further developments during the middle Ages were the most threatening danger of dissolution of ethnicities and cultures throughout the Balkans, but the well preserved/isolated Albanian ethno-genesis either from culture, origin and territory, was what challenged this by preserving the pure ethnic and cultural features.

It was these that in different forms tried to eradicate the Albanian people, ranging from assimilation and up to biological eradication. This also proves that when the territory of Kosovo today, in medieval times were changed many rulers, such as the Romans, Byzantines, Bulgarians, Macedonians, Serbs and Turks, to continue later, until recent years in the XX century.

The fact that the Albanian people is in these lands, preserving for generations and centuries, language and culture, proves its existence as an ancient people. It has given and taken from the neighbouring people and cultures, but always retained its identity.

Actually, the general underdevelopment, territorial compactness of population and geographical and socio-cultural isolation, influenced the Albanians in general be kept as national and ethnic community, despite the secular efforts of rulers and occupiers to assimilate, to displace in remote areas or even to eradicate them. (Islami, 1981)

Their occupying history had continued about one hundred years after the declaration of Albanian state, including the entire twentieth century. However, even this did not achieve its goals; they guarded and defended the dignity of being Albanian.

Having its roots in the values that most closely relate to the protection and preservation of the clan and family, Albanianism emerged as a modern elaboration of traditional notions embedded in centuries and different from the idea of the nation, which was characteristic for those years. (Rago, 2011)

History shows various forms of social organization, depending on the invaders who changed so from the Romans to the Slavs of the twentieth century. Despite this, all settlements in Kosovo managed to build and preserve its history and the history of all Kosovo. Some previously created some later, with changes in designations and history, once Roman, then Byzantine, Slavic, Bulgarian, Ottoman again Slavic, with population persecuted and mutilated, but never submissive, ultimately remained pure Albanian settlements since their genesis.

Whenever it comes to researching the distant past, science constantly continues to uncover new facts and documents, as every day and discovered new artefacts, and which in some cases deny the ones so far. This is enabled by the modern tools of the latest technology, which is enabling explained by more advanced methods.

It is precisely these methods that argue that the ancestors of today's Albanians have lived in their lands for centuries before the Romans and the Greeks, and who have faithfully preserved and transmitted its customs and traditions from generation 
to generation. They have even managed to preserve and convey the common habits of people with whom they had been neighbours even better and more originally than they themselves.

\section{Gjakova with its surroundings in anthropological and historical context}

One of the earliest settlements and with a pure and proud history, proven through various times in history, and that from the twilight times is also the settlement called Gjakova and its surroundings.

Anthropology and history of the Albanian people of Gjakova, as indigenous people and descendants of the Illyrians, presents a story on its own, which besides being very loud, not only for itself but also for other peoples of the Balkans and Europe, is also very glorious. This is also enforced by archaeological findings, which proves of "a thriving life in this region since prehistory to the Middle Ages. (Shukriu, 2002)

Thanks to its suitable geographical position throughout history, Gjakova with its surrounding had very good conditions for growth and challenge to all past historical periods, however severe they were.

Referring to the geographical position, assets and natural goods which consist of in one hand the rich mine of Deva and on the other hand the fertile plains traversed by two rivers: Drini in the east, which is of great importance since it connects the Adriatic sea with the central Balkan, and Erenik in west and south, as well as the structure of the terrain of Gjakova with the surrounding, are proven facts and arguments that these lands had been inhabited since prehistoric times. This is also proven by the findings of artefacts on this area, which belong to the Illyrians who lived in these areas, findings that are coming to light day by day.

Documentary sources from different backgrounds demonstrate the continuity of Albanian native population in the region of Gjakova from Illyrian-Dardan time until the twentieth century and beyond. This conclusion does not exclude neither the changes that have occurred over the centuries due to migratory processes, related to the political factors, foreign conquests, with the economic and social ones, etc. These factors have resulted in the presence of other ethnic elements in this province and in the dividing of its people sin different religions, the Muslims, Catholics, partially Orthodox. But even in these circumstances Albanians remained the dominant population in the region of Gjakova, which is noted for its ethnic homogeneity. (Bajraktari, 1998)

Regarding the way Gjakova was established different opinions are given, many of which lack the supporting documentation.

The facts and historical records indicate that Gjakova is known since fifth decade of the XIV century and that since 1348. During this time it belonged to the Alltun-Ihlia Nahija (Nahijë was an administrative unit in the Ottoman Empire. Its administrative system responds to the level of a municipality in Kosovo) based in Junik. On the other hand, based on the sources of material culture, monumental architectural constructions, it is known from the last decade of the XVI century.

However, for the first time in the middle Ages, in 1485, Gjakova, is referred to as a bazaar village-place. According to Turkish defter (defter-land cadastre in Turkish Empire) the year 1485 had 54 houses that responds to respective counting of families or about 300 residents.

Based on what they talked and argued that until 1582 Gjakova was as shopping centre and countryside, its convenient geographical position as well as importance in strategic aspect, created the opportunity for a rapid development in time, making it a centre of connections between Shkodra, Sanxhak and other surrounding places. (Shkelzen \& Blerim Zajmi, 2010)

The city as an urban centre dates from the late XVI century when the foundations are laid for the impressive Mosque - of Khadim Aga in 1001-1003 according to Muslim calendar (years 1592-1594). Until then there was the central homonym rustic dwelling where the weekly market was held for this area.

Only about half a century after the establishment of the Mosque of Khadim-Aga, Gjakova is described by foreigners as a city with outstanding craftsmanship and trade. (Lleshi, 1987)

So Gjakova was founded as a city at the time of the Ottoman rule. The old part of the town was built in the space between Krena and Çabrat. Hadum Suleiman Efendi, known as Hadum-aga, built a mosque in 1594/5, which was named after the 
founder Hadum's mosque. At the same time they built an inn and a hammam. According to people's tradition, these important objects of the city are built in the field of Jak Vula, hence the name of the city is Jakova. Around Hadum's mosque was built the Grand Bazaar. In its vicinity were set the homes of noblemen. They built large towers built in the square called the Clock field. (Osmani, 2010)

From these data we come to the conclusion that Gjakova was inhabited since old times, was formed as a town in the late $\mathrm{XVI}$ and early XVII century, while in the middle of the XVII century it became one of the largest cities in Kosovo. Throughout this time (since its establishment until 1878) Gjakova was one of the most important economic, political and strategic centres of Kosovo and as such has attracted the attention not only of the Ottoman administration, but also of many missionaries and diplomats, clergymen, travellers and scientists of the time.

That this place was really inhabited since ancient times to keep up with current developments becoming a known centre is also proven by the writings and reviews of some of the personalities of the time who had been fortunate enough to pass through this region. (Bajraktari, 1998)

Archbishop of Bar Gjergj Bardhi in 1637/38, begins his report with Gjakova, who also during another visit in 1641/42 mentioned Gjakova.

Turkish geographer Haxhi Kallfa (around 1635) mentions Gjakova- Jakova- small town located between Peja, Vushtri, Pristina and Prizren. While the Altun-lli, he writes that it is located: between Peja, Gjakova, Podlima. Prefect of Catholic missions in Albania, Frater Cherub, on March 27, 1638 wrote inter alia: ". . As you pass Gashi for half of a day, there is the province of Jakova in a very nice field, where there are many villages. . . ". (Osmani, 2010)

Evliya Çelebi was the Ottoman traveler, who for the first time in 1662 mentioned Gjakova as a city. According to him, Gjakova was an advanced settlement, Gjakova people were good people and beautiful and that it had had 2,000 homes, two beautiful mosques, inns covered with lead, a hammam and 300 shops with many kind of crafts.

Also in some Austrian reports by the end of the XVII century is mentioned Gjakova, which was estimated that it had many villages.

Some data on Gjakova are brought and shown by J. Muller, a former employee of the Austrian consulate in Shkodra, and in his report of 1838, he gives concrete proof for the population of this area dividing them based on religion and neighbourhoods of that time.

A. Gilferding Russian traveller, who, during his trip through Herzegovina, Bosnia and Kosovo, visited this region in 1857 and wrote that Gjakova was a town inhabited by Albanians, where tribal way of life prevailed. The basis of the way of living of Albanians from here, according to him, constitutes the tribe. In Gjakova, according to him, the Albanian element is more emphasised than in any other place.

Sometime around the 40's of the XIX century, also in Gjakova started appearing first elements of capitalist relations, leaving aside those feudal ones until then. This brought the capitulation of the system of known Gjakovar crafts since the Middle Ages, through which craftsmanship was organized, as well as opening of a market between other cities as well as other countries. This brought a more stable and stronger economy.

Based on the toponymic arguments, Gjakova with surroundings results as the place with the greatest number of pure Albanian named areas and preserving old track of ancient Albanian descent. This proves the fact that this population lives on in its land.

XIX century marks a significant turning point in the economic, political and cultural life of the Balkan people within this the Albanian people, respectively the people of Gjakova and its surroundings. This population, as we saw, took an active part in all the events of the time, giving its contribution in different areas of life. Gjakova Albanians were activating not only in political events, but also in the economic, material as well as a cultural and artistic ones. Gjakova area and its surrounding in the XIX century and early XX century takes an important position in all of these areas, not only in Kosovo, but also beyond.

Developments in history significantly influenced also the general anthropological issue of ancestors of the Albanian people, and also in Gjakova and its surroundings, ie since the early Albanian language with Pelasgian-Illyrian origin up to today's 
Albanian language. Based on the "historical documents, Gjakova exists as a settlement from early times, but as the city it's one of the newest cities of Kosovo". (Haxhosaj, 2012)

The organization of social life in administrative and territorial terms depended on the rulers whereas occasionally it wound undergo changes and that based on their invasive interests.

Even this part was a part of the Roman conquest, after the division of the empire, it remained under Byzantine occupation. Later Gjakova with the surroundings was under Bulgarian rule and later in the Middle Ages under the Serbian-Slav. In the medieval documentation of that time, where there are very few historical sources, the area is mentioned by names Patkovë, Reka and Alltin. Forms of naming the city underwent changes over the centuries.

While in the XIX century Gjakova with the surroundings possessed a territorial space much larger than today, SerbMontenegrin invasion in 1913 gave it the administrative form of today. After 1963 there were no territorial administrative changes.

After the declaration of independence of the Albanian state, Gjakova was occupied by Serbian-Montenegrin, who continued the destruction of everything, populating it with Montenegrins and Serbs up to the assimilation and conversion of the population of this area.

During World War I Gjakova with the surroundings were under the rule of Austria-Hungary and after the war back was again retaken by Serb-Montenegrins and that by performing colonization in almost every part of it.

However, despite these challenges, Gjakova managed to preserve the pure Albanian language, culture and traditions and is today the city with the earliest literary tradition and culture. According to the author Halil Haxhosaj, literary beginnings (poetry) with historical and religious value but not so with aesthetic value, dating from the XV century with the poetry of Sulejman Effendi-Harxhiza Baba, who was with origin from the famous family Bushataj of Shkodra and who was the founder of famous Masjid in Gjakova and Kosovo, The Great Masjid. Also one of the fruitful creators from Gjakova was Tahir Efendi Boshnjaku. (Haxhosaj, 2012)

Gjakova with surrounding is in the central part of Dukagjini area and has $586 \mathrm{~km} 2$, ie $5: 38 \%$ of the territory of Kosovo, at an altitude of $365 \mathrm{~m}$. (lowest in Kosovo), while in mountainous areas it reaches a height of up to $2305 \mathrm{~m}$, which makes us understand the difference of the relief is quite highlighted in a strategic position between North Albania and Kosovo centre and consists of 87 settlements

\section{1 Preserving the traditions and cultural heritage}

Cultural traditions of this area is associated the same with the Albanian one in general, known since Neolithic time and developed as indigenous. This culture develops its journey in the footsteps of time changes and its advancement, going even through the Age of bronze and iron and medieval. These were really periods where there were movements and large blossoms on the cultural level in all human societies, where mutual borrowings were inevitable. However, persistence and continuity in the sustainable lands just made continuous shaping of culture of this region, being indigenous and reaching the highest degree of development.

Albanian Gjakovar culture and one developed as indigenous culture and at the same time with Indo-European process. This was confirmed also by our language, which has roots from the Indo-European languages, proven since ancient authors up to more recent studies.

The fact itself of the existence on its lands and preservation of culture and language are evidence of the antiquity of this population.

Archaeological discoveries in the territory of Gjakova indicate that in this area is present the organized process of urban life since the most ancient times. So with all Albanian folk cultural values, architecture, sculpture, habits and Dardania customs inherited from: Antic time, Rome, Byzantium, the Middle Ages, the Ottomans, and the completion of new construction preserve a emphasized continuity. 
The organization and functioning of this area was special. Many times it was the model of social organizations not only to Albanian society. The patriarchal family was the prevailing form in Gjakova as well, as in almost all Albanians, and it was organized under the common law. Some passer-by who passed by were first astonished with the order, culture and traditions of this area, which really were typical traditional and timely. Population of this area kept and cultivated with 'fanaticism' crafts inherited through generations, also following the developments of the time. Gjakovar families are known for passing the crafts of their ancestors from generations to generations which are mentioned in their surnames. So today we have Gjakova families with surnames Sahatcija, Çarkagjija Tabaku, Oven, Kazaz, Gunpowder, Nallbani, Kamishi etc.

According to prof. Masar Rizvanolli, (Rizvanolli, 2009) Gjakova has a rich tradition of education and culture, tradition, which started with the beginning of its civic life.

It was exactly these that imposed to the Kosovar Albanian population to get traditionally embedded to their native country. What made this people traditionally special was their relationship with the family and place of birth, which they always defended with wars and blood.

This is also expressed by albanolog - scholar Franz Nopcsa, who says: "As all the peoples of the patriarchal cycle in the Balkan Peninsula also Albanians are distinguished by clear firm moral sense, for their morality almost harsh, for straight ways, often wild, of action.

The have a strong sense of community of the tribe and family and, at the same time, show a spirit of sacrifice, not discouraged before any obstacle. (Nopça, 2013)

Referring to the geographical position, assets and natural assets and the structure of the terrain of Gjakova and its surrounding are proven facts and arguments that these lands had been inhabited since prehistoric times. This is also evidenced by the findings of artefacts on this side, which belong to the lllyrians who lived in these areas, findings that are coming out day to day. Construction or material culture is typical in these parts. We are talking about a significant number of cultural heritage monuments Gjakova municipality has these cultural-historical monuments:

\section{Conclusion}

Referring to numerous scientific studies and finding of many new artefacts, it is already clear that anthropological and historical ethno-genesis of Gjakovas' Albanian society is

Passed by and inherited from the lllyrian-Dardans.

The fact itself of the existence in its lands and preservation of culture and language are evidence of the century antiquity of this population. All historical challenges have accompanied the Albanian society through generations. However, despite the social evolution, it has maintained its tradition and culture with fanaticism. Part of this 'preservation' was also Gjakovar Albanian society. Exactly, culture was the most powerful weapon of Albanian society that challenged all the storms of history and managed to get out triumphant.

The way of life on itself and internal social organization was special, and it was taken as a model by other Albanian societies.

Albanian culture and Gjakovar one developed as indigenous culture at the same time as the Indo- European process. However, Gjakovar territory is known for preserving "intact" traditions and pure culture since its ethno-genesis.

This is also evidenced by passing by through generations of surnames according to crafts they worked, surnames that even nowadays exist and that still try to preserve part of their tradition, and from the large number of many objects of heritage that are in this region and clearly show the continuity of the historical - anthropological genesis of this pure Albanian society and with traditions and customs passed by from generation to generation.

\section{References:}

[1] Bajraktari, J. (1998). Gjakova with surrounding (1878-1912). Prishtina: Institute of History.

[2] Haxhosaj, H. (2012). Literary club "Gjon N. Kazazi” - Monograph. Gjakova: Literary Club "Gjon N. Kazazi”. 
[3] Islami, H. (1981). Population of Kosova, demographic study. Prishtina: Organ for Texts and educational means of Socialistic Autonomous Province of Kosova.

[4] Këpuska, A. (2004). Essence of the territory and ethnic indigenous borders of Kosovo. Prishtina: Rilindja.

[5] Krasniqi, M. (2002). Our ethnical roots. Prishtina: Dukagjini.

[6] Lleshi, Q. (1987). School in Gjakova, its foundation and first generation 1946-1948. Prishtina: Rilindja.

[7] Nopça, F. (2013). Tribes of Malesia of northern Albania and their common law. Tirana: Eneas.

[8] Osmani, J. (2010). Kosova's settlements - Gjakova 14. Prishtina: Karnime.

[9] Pirraku, M. (1989). National Albanian Culture until the Prizren League. Prishtina: Albanology Institute of Prishtina.

[10] Rago, P. (2011). Tradition, nacionalizm and communizm in modern Albania. Tirana: Dudaj.

[11] Rizvanolli, M. (2009). Development of Albanian Education in Gjakova until 1918, K. D. U. 37 (496. 51) (092). Kosova 31/32. Prishtina: Institute of History K. D. U. 94 (=18).

[12] Shkelzen \& Blerim Zajmi. (2010). Family Zajmi - over 250 years nursery of the pen, weapon and patriotism. Gjakova: Association of Intellectuals "Jakova.

[13] Shukriu, E. (2002). Archeologic heritage in the context of toponym changes. at: Toponymy of Gjakova with surrounding. Gjakova: Blini - BK.

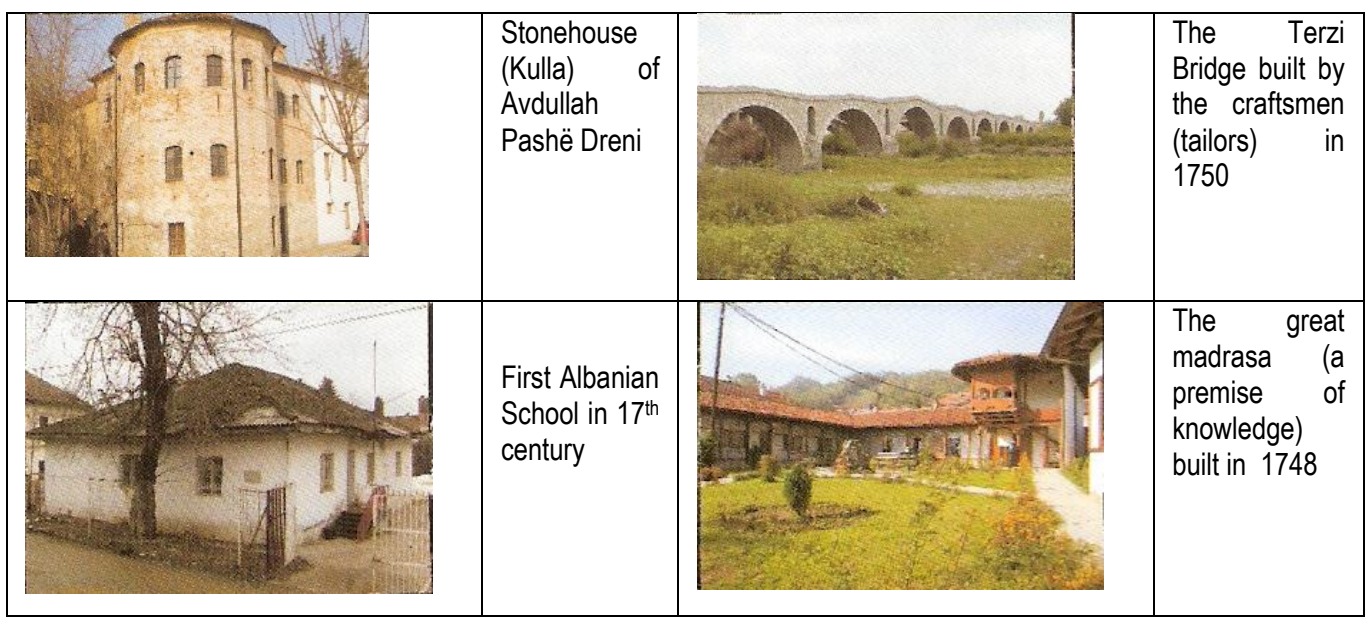




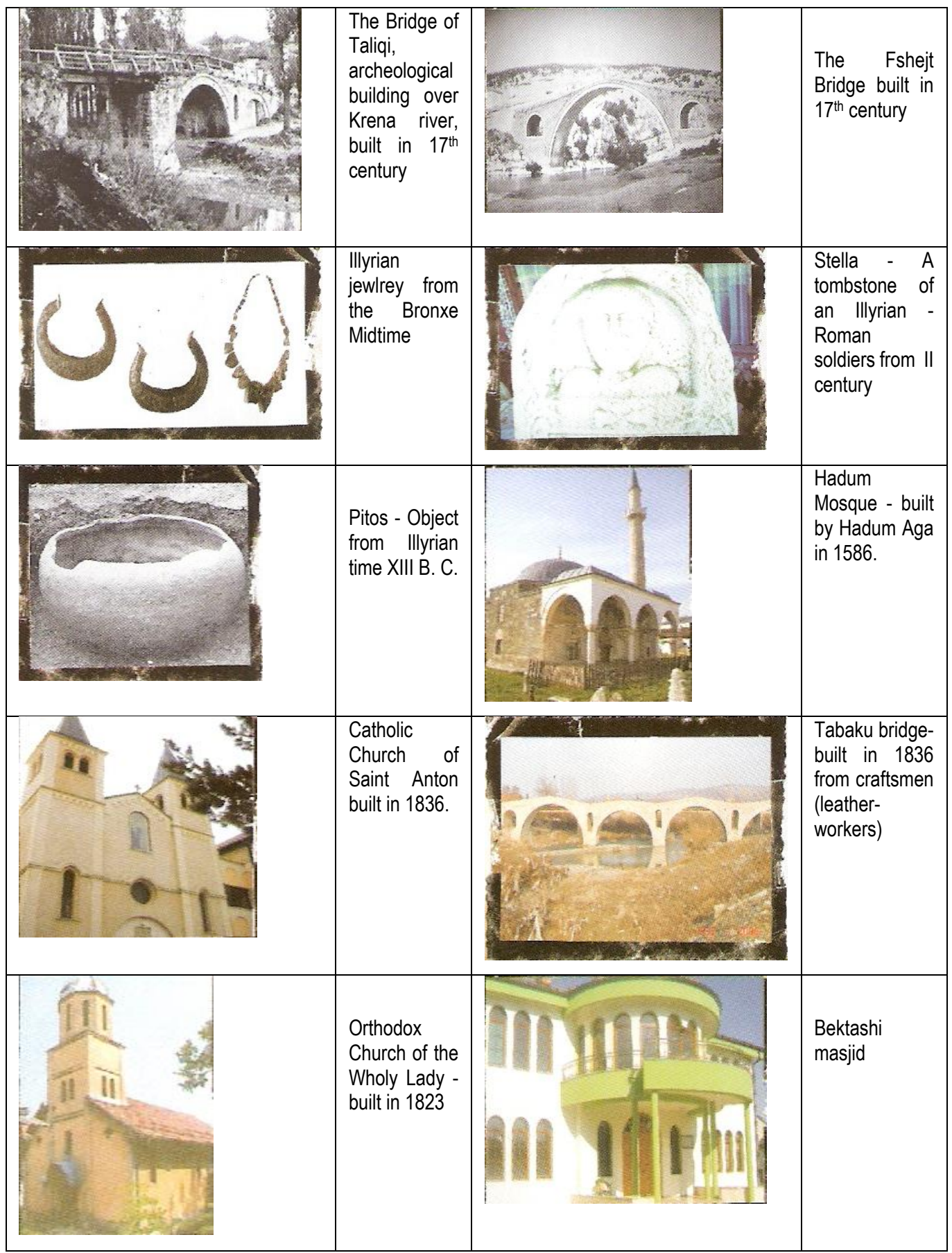




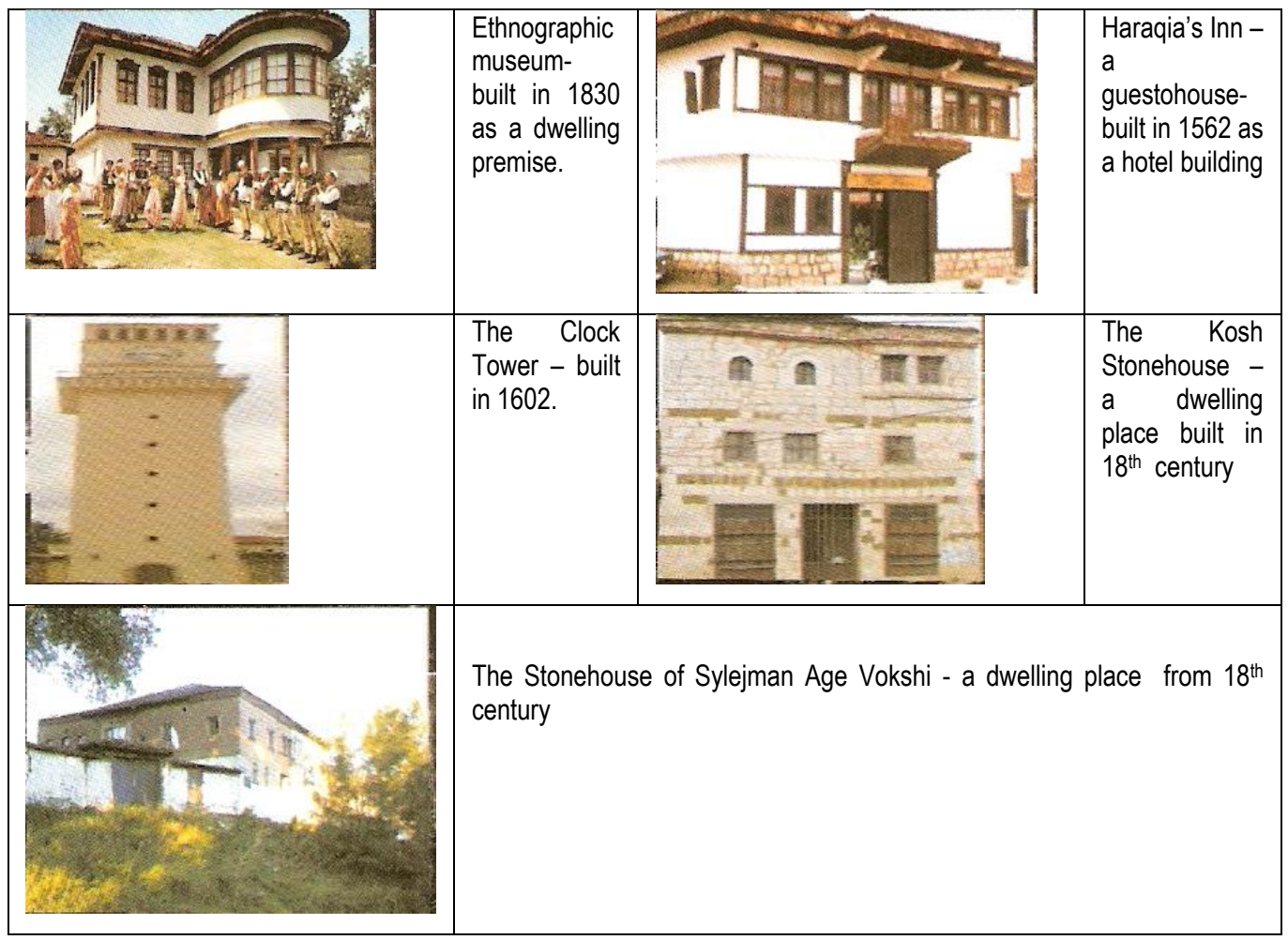

\begin{tabular}{|l|l|l|}
\hline & Type of cultural heritage & Number of buildings \\
\hline 1 & Archeological locations & 10 \\
\hline 2 & Sacral Curch monuments & 14 \\
\hline 3 & Sacral Islam monuments & 26 \\
\hline 4 & Shrines & 20 \\
\hline 5 & Mejtepe & 4 \\
\hline 6 & Madrasa & 2 \\
\hline 7 & Masjid & 16 \\
\hline 8 & Clock Towers & 1 \\
\hline 9 & Stonehouses & 128 \\
\hline 10 & Cemetery complexes & 9 \\
\hline 11 & Mills & 7 \\
\hline 12 & Monumental bridges & 4 \\
\hline 13 & Architectonic-urbanistic complex of the Old Bazar & 1 \\
\hline 14 & Craft Centre & 1 \\
\hline 15 & Monumental Houses & 50 \\
\hline 16 & Inns/ Guesthouses & 4 \\
\hline 17 & Monumental fountain-heads & 6 \\
\hline 18 & Barns and backets & 15 \\
\hline
\end{tabular}

